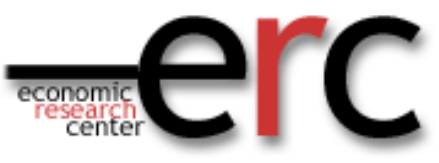

ERC Working Papers in Economics 11/01 March 2011

\title{
An Analysis of Political and Institutional Power Dispersion: The Case of Turkey
}

\author{
Ibrahim Tutar \\ Penetra Consulting \\ Cumhuriyet Caddesi, No: 79-6, Suna Apt. Elmadağ \\ Şişli 34360 İstanbul \\ Tel: 0090(212)234 7077 Fax: 0090(212)234 7076 \\ Email: Ibrahim.tutar@penetra.com.tr \\ Aysit Tansel \\ Department of Economics \\ Middle East Technical University \\ Ankara 06531 Turkey \\ Email: atansel@metu.edu.tr \\ Tel: 0090(312)2102057 \\ Institute for the Study of Labor (IZA) Bonn, Germany \\ and \\ Economic Research Forum (ERF) Cairo, Egypt
}




\title{
An Analysis of Political and Institutional Power Dispersion: The Case of Turkey*
}

\author{
Ibrahim Tutar \\ Penetra Consulting \\ Cumhuriyet Caddesi, No.79-6, Suna Apt, Elmadag, Sisli 34360 Istanbul \\ Tel: 0090(212)234 7077, Fax: 0090(212)2347076 \\ Ibrahim.tutar@penetra.com.tr \\ and \\ Aysit Tansel \\ Department of Economics, Middle East Technical University, 06531 Ankara, Turkey \\ and \\ Institute for the Study of Labor (IZA) Bonn, Germany \\ and \\ Economic Research Forum (ERF) Cairo, Egypt \\ Tel: 0090(312) 2102057 \\ atansel@metu.edu.tr
}

\begin{abstract}
:
This study examines the effects of fragmented governments and fiscal authorities on budget deficits in Turkey along with political business cycle effects. For econometric analysis we will use annual data from the period of 1960-2009. This paper sheds light on various dispersion indices and their use in the field of political power and fiscal performance. The results show that the power dispersion indices of governments and fiscal institutions significantly explain the increases in the ratio of budget deficit to GNP. The paper draws attention to the unification and better coordination of fiscal authorities in Turkey. The analysis has important policy implications for Turkey and other developing countries from the viewpoint of fragmented political and administrative dispersion of power and poor budget performances.
\end{abstract}

Key Words: Political Business Cycles, Fragmentation and Power Dispersion, Public Budget, Turkey, Statistical Indices

JEL Classification: P16, H72, C22, C43

\footnotetext{
*We would like to thank the two anonymous referees and the editor Wade Martin for their valuable comments and insights. All remaining errors and omissions are our own.
} 


\section{Introduction}

In developing countries, in particular, not only are the governments the largest employers but also the government budgets constitute the most important resource allocation mechanism. In these countries, on average, 30 percent of the gross domestic product (GDP) is allocated by the government budgets. The purpose of this paper is to investigate the government budgets in relation to a number of political events and institutional factors in Turkey. In this regard, we consider elections and military-backed governments as political events. The institutional factors that are considered include organizational fragmentation of the budgetary institutions and the coalition governments. Examining the effects of the elections on budget deficits might give an indication of the existence of political business cycles in Turkey ${ }^{1,2}$. The novelty in our approach is that we introduce a new power dispersion index which is suitable for the conditions of Turkey and probably for other developing countries that have fragmented fiscal authorities under the coalition governments. These and similar issues are investigated extensively in developed countries but less often in developing countries. Therefore, the analysis in this paper is expected to be useful for the policymakers in Turkey and other developing countries.

In Turkey, since 1983, there have been two separate organizations responsible for the preparation and implementation of the budget, whereas only a single organization was responsible before 1984. These organizations are the Ministry of Finance (MOF) and the Undersecretariat of Treasury (UT). UT is responsible for financial aspects of the budget especially including debt management of the budget and some important transfer expenditures such as funds, subsidies and incentives. The MOF determines the appropriation of current and transfer expenditures, regulates the dates of the expenses, and accrues and collects the revenues. It is known that the State Planning Organization (SPO) is the third organization that is involved in the budget process; but since the SPO mainly prepares the macroeconomic framework of the budget, it may be considered as more an advisory board of the government rather than an administrative board. For this reason, we will consider only the MOF and the UT in our analysis. We claim that the power division between these two organizations exacerbates the political power dispersion of coalitions. In order to test this claim, we will test the previous power dispersion indices and then introduce an index that takes into 
account the interaction between these organizations and the number of parties in the coalitions. Analysis will shed light on the necessary fiscal reforms and fiscal policies required to reduce budget deficits.

This paper is organized as follows: Section 1 reviews the literature and explains the model used. The historical background of main economic events in Turkey and the data used in the analysis are explained in Section 2. Empirical results are provided in Section 3. Policy implications are discussed in Section 4. And finally, Section 5 gives the conclusions.

\section{Review of Literature and the Model}

The topic of how political and institutional considerations affect the national fiscal policy formation recently attracted the attention of many researchers. This line of argument starts with the seminal study by Roubini and Sachs(1989a) which is based on a cross-section data of 14 OECD countries. They show that the tax smoothing hypothesis cannot fully account for the differing magnitude of the budget deficits because it does not take the various institutional arrangements in the political processes into account. They test a semireduced form equation to see effects of the political power dispersion on the budget deficits. This model is consistent with both the tax smoothing hypothesis that is championed by Barro(1979) and the traditional Keynesian model of fiscal deficit discussed by Haan et al. (1999, p.166). The Roubini and Sachs model is as follows:

$$
Y_{t}=a_{0}+a_{1} Y_{t}+a_{2} U N_{t}+a_{3} R B_{t}+a_{4} D N_{t}+a_{5} P O L_{t}+v_{t}(1)
$$

where the dependent variable (Y) is the net public debt/GDP ratio. YL is the lagged dependent variable, UN is the change in the unemployment rate, $\mathrm{RB}$ is the change in debt service costs, $\mathrm{DN}$ is the change in real GDP growth rate, POL is the political-institutional variable and $v_{t}$ denotes the error term ${ }^{3}$. Their results show that public debt increases as the number of parties in a coalition government increases. As suggested by the game theory, coalition governments find it difficult to cooperate. This is referred to as the Prisoner's Dilemma. Since coalition partners have different constituencies, each party will veto spending cuts that interfere with the interests of their respective constituencies. 
Although researchers agree that political factors in determining the budget deficits should be taken into account, there is no consensus on how to measure the effect of these factors. Edin and Ohlsson (1991) rightly object to the way the political power dispersion index is constructed by Roubini and Sachs ${ }^{4}$. The Roubini and Sachs index (POL) implicitly assumes that the increase of public debt under a minority government is three times as large as that under a two-party majority coalition. According to Edin and Ohlsson, the political index should have a non-linear form with which every class of government's political cohesion could be tested separately. They construct separate indices, namely POL1, POL2, and POL3, which account for the cohesion of the two- party governments, three- and more party governments and the minority governments, respectively. Using these dummy variables in the Model (1), they find that the estimated significant political effect which is interpreted by Roubini and Sachs as the coalition effect is in fact entirely due to the effect of the minority governments. They find that none of the POL variables were significant for the European Union countries. They conclude that government debt accumulation is positively associated with the frequency of government changes.

The Haan and Sturm (1997) study differs from Haan and Sturm (1994) in three aspects. First, they use gross debt/GDP ratio as the dependent variable instead of net debt/GDP ratio. Second, they consider the data of 21 OECD countries instead of 14. Third, their sample period (1982-1992) differs from that of the previous studies (1960-1985). They use the same class of political variables like POL1, POL2 and POL3 and estimate a model similar to the Model (1). They find that none of these dummy variables are significant in explaining the gross and net debt to GDP ratios, and the government consumption and investment spending in GDP. They redo the analysis for the 1960-1985 period, and find again that the effects of power dispersion index are insignificant.

The most recent research on fragmented governments and dispersion of political power was done by Perotti and Kontopoulos (1998), Kontopoulos and Perotti (1999), Haan, et al. (1999), Volkerink and Haan (2000), Franzese (2002), Ricciuti (2002), and Huber, et al.(2003). Perotti and Kontopoulos base their research on 1960-1985 data of 20 OECD countries. They define fragmentation as the number of the decision-makers (size fragmentation) and the dispersion of the structure of the process in which decision-makers interact (procedural fragmentation). They use the number of the parties in the coalition and the number of the 
spending ministers to measure the two forms of fragmentation, respectively. They use the central government expenditures and deficits as dependent variables. Their results show that fragmentation does matter, especially for transfers and personnel payments. Kontopoulos and Perotti (1999) stress that spending has a public-good-effect while the burden of the spending is a public bad. Effects of the spending are internalized by the decision-makers while the (tax) burden of it is born by the whole economy.

Haan, et al. (1999) base their research on the data of 20 European countries for the period 1979-1995. Their model is a variant of the Model (1) above. Their dependent variables are growth of gross and net debt for both central and general government. In contrast to Roubini and Sachs (1989a) and Edin and Ohlsson (1991), they cannot find supporting evidence in favor of POL or POL1, POL2 and POL3 type variables. They conclude that it is the number of parties in a government that matters for the debt/GDP ratio not whether or not the government has majority in the parliament. Volkerink and Haan (2000) use a panel of 22 OECD countries over the 1971-1996 period with central government expenditures and deficit as the dependent variable in the Model (1). They propose new variables such as the government's position with respect to the parliament, ideological complexion and political fragmentation of the government. They conclude that the impact of the number of ministers is more robust than the number of parties in the government, and political fragmentation does not seem to affect the deficit.

Ricciuti (2002) uses data of the 19 OECD countries for the period 1975-1995. As for institutional fragmentation, Ricciuti uses the number of the veto players and their orientation in the decision-making procedures in addition to Roubini and Sachs's (1989) POL index. Moreover, he uses roles of the house and the senate and the threshold values for the representation to measure political cohesion. For the first time, Ricciuti uses the elections as an explanatory variable and finds that the number of spending ministers, institutional fragmentation, elections, electoral years and a mandatory limit on a re-election have significant effects on government expenditures. Huber, Kocher and Sutter (2003) test the influence of strength and power dispersion of coalition governments on the size of annual debt accumulation in OECD countries from 1970 to 1999 by using the Model (1). They propose and use the Banzhaf index of voting power in order to measure the fragmentation degree within the coalition government and to address the power of coalition members for making or breaking governments. They use the standard deviation, which is named 
'Dispersion', to measure dispersion of the voting power of parties in coalition governments. They conclude that they do not find any support for the hypothesis that stronger governments have lower budget deficits or accumulate less debt. They find that a higher dispersion of voting power of coalition members of a government leads to less debt accumulation. This means that equally strong coalition partners tend to block each other and cause non-cooperative outcomes, whereas differing levels of voting power of coalition partners are better in achieving a successful stabilization of their debt levels.

In addition to the effects of the fragmentation in governments, several researchers also examine the effects of elections on budget deficits. Assuming that governments are able to move the economy according to their desires, and voters behave in a myopic manner; models developed for this purpose show that politicians are inclined to run budget deficits (decrease unemployment) before the elections and follow contractionary budget policies (decrease inflation) after the elections (Nordhaus 1975 and 1989). However, the contraction after the elections is usually postponed and the expected austerity never happens. These models are called political business cycle (PBC) models. The macroeconomic fluctuations may also be explained by the partisanship attitudes of the governments. For example, Hibbs (1977) shows that governments broadly act in accordance with their parties' economic and social objectives and their class-defined political constituencies. Schuknecht (1996) examines PBCs and partisanship behaviors for a set of developing countries. He finds that governments of developing countries engage in expansionary fiscal policies before the elections in order to enhance their re-election prospects and contractionary policies after the elections. Franzese (2002) states that incumbents seem more prone to manipulate direct transfers than macroeconomic policies, at least for electoral purposes; and perhaps more prone to manipulate the timing of policy implementation than policies themselves.

As the preceding review makes it clear, this topic is studied mostly in developed countries but less often in developing countries. Therefore, the analysis in this paper has important policy implications for Turkey and other developing countries. There are a few studies on this topic in Turkey. Özatay (1999) uses quarterly data for the period of 1985-1995 to show that elections have significant effects on economic policies. He also finds some evidence of inflationary effects of these populist policies, since the prices of the public goods and services increase after the elections. He uses the money base, net assets of the central bank, fiscal 
variables such as government expenditures and the public sector prices as dependent variables. He suggests institutional changes such as the independence of the central bank.. Ergun (2000) investigates the electoral cycles during the period of 1985-1999. She uses extensive series of monthly data to test the existence of political business cycles from monetary, fiscal and pricing policy perspectives. She finds that before the elections, fiscal expenditures especially transfer payments and the monetary aggregates increase, while tax revenues and the prices of public goods and services decrease. Kuştepeli and Önel (2005) tested the effects of fragmentation and polarization of the coalition governments by using Edin and Ohlsson's POL1, POL2 and POL3 variables and a variable for the ideology of governments. They used 1976-2004 data for Turkey. They found that fragmentation of the coalition governments have only minor effects in increasing the debt/GDP ratio. The ideology of governments has significant effects only if the number of parties in the government is taken into account. In general, they conclude that fragmentation, polarization and ideology do not play important roles in explaining the budget deficits in Turkey.

\section{Economic Background and the Data}

In this study we analyzed the period of 1960-2009 in Turkey. This period covers a number of important political and economic events. The period of 1960-1980 was characterized by import substitution policies. On January 24, 1980, the Structural Adjustment and Stabilization program was implemented. This date marks the beginning of a period during which major policy switches occurred. Some of these changes are as follows. In July 1980, interest rate ceilings were abolished. In May 1981, the exchange rate began to float. In 1983, the foreign trade regime was liberalized and export-led growth policies were adopted. The Undersecretariat of the Treasury was separated from the Ministry of Finance. Eventually, the Treasury became a powerful government body managing the debt and cash-flow policies. This increased the number of fiscal authorities responsible for the economic and fiscal policies. The so-called institutional fragmentation occurred after this period (i.e. after 1983). In addition to the Ministry of Finance and the Treasury, the State Planning Organization (SPO) was also involved in economic decisions. The SPO continued to draft five-year plans and annual investment programs. The early 1960s, 1970s and the early 1980s witnessed the military-backed governments. The early 1960s, the late 1970s and the 1990s were 
characterized by coalition governments. Petroleum price shocks occurred in 1974 and 1979 that overlap with the second period of coalition governments. According to Sayari (1996/97), the third period of coalition governments began after the 1991 elections, which was mainly caused by the failure of completion of economic reforms. One-party dominance that began in 1983 ended in 1991. Turkey experienced two financial crises: One was in 1994, and the other was in 2001; both of which occurred during coalition periods. The 1994 crisis stemmed from an unsustainable level of public debt; and the 2001 crisis originated from an unsustainable fixed exchange rate regime, based on the neo-Keynesian approach to the sticky price models and inertial inflation. After 2001, the floating exchange rate regime was put into effect and financial institutions were tightened to create tight money and credit policies.

In this study we propose to examine the effects of economic and political events, such as the power dispersion among the political and fiscal authorities, on the budget deficit. Thus, the dependent variables are the ratios of budget deficit, expenditure and revenues to GNP. The explanatory variables are GNP growth rate, inflation rate, the volume of trade/ GNP ratio as an index of openness of the economy, and a number of dummy variables representing the economic and political events referred to above. Our basic model follows the Roubini and Sachs model given in Model (1), except that we cannot include the unemployment rate and cost of public debt among our explanatory variables, since no reliable and complete series exist for Turkey with these variables during the period under consideration. Instead we use the GNP growth rate, inflation rate and openness index to capture the income and price effects.

Table 1 shows the dates of the elections, the types of governments, and the duration of the governments in Turkey. We can observe from this table that Turkey has been governed by coalition governments for several periods of time during the 1960-2009 period.

\section{Insert TABLE 1}

Table 2 shows the average deficit /GNP ratio, growth rate and the inflation rate over some sub-periods in the 1960-2009 period. 
Insert TABLE 2

From Table 2, we first observe that the inflation rate and the budget deficits were the worst during the 19842009 period. The best period in all terms was the period of 1962-1970. Second, during the military or military-backed governments (1960-61, 1971-1973 and 1981-1983), the budget deficits and inflation were higher than they had been during the elect governments of the 1962-1974 period but lower than they had been during the elect governments of the 1974-1980 and 1984-2009 periods. Third, despite the higher budget deficits and inflation rates, the period of 1984-2009 witnessed lower average growth rate compared to the average growth rate of the 1960-2009 period. The extraordinary governments seem to be successful on average compared to the elect-governments of the whole period. Figure 1 shows that the budget deficit/GNP ratio was always negative after 1970. 1976 was the beginning of a high inflationary period. From 1976 to 2004, the inflation rate was always at two-digit levels and even in 1980 and 1994 reached three-digit numbers. Since 2005 onwards, the inflation rate dropped to single-digit numbers. This was due to the gradual ending of populist economic policies and the successful privatization projects, all of which were coordinated with the help of the IMF.

\section{Insert (FIGURE 1)}

Figure 2 exhibits the inflation rate and the number of parties in the governments. It shows that there are three main coalition periods between 1960-2009. The first is during 1961-1969 just after the first extraordinary government. The second is during 1973-1979 just before the third extraordinary government. The third coalition period is from 1991-November 2002.

\section{Insert (FIGURE 2)}

Table 1 together with Figures 1 and 2 show that there might be a correlation between the political and the economic instability, yet the direction of the causality is not clear. The burden of the stability depends on the 
high growth performance and the 'soft budget constraint' of the state (Önis and Riedel, 1993). In other words, in order to satisfy the majority of voters, regardless of the cost of the resources, the governments should provide a positive growth rate and, at the same time, should increase the budget transfers ${ }^{5}$. Atiyas (1996) makes a similar argument. Atiyas and Sayin (1997) propose a principal-agent model in order to understand the budgetary allocation issue in Turkey. They consider the voters as the principals during the elections but, after the elections, the politicians become the principals and bureaucrats become the agents. It is a very difficult task for principals to manage the agents because of the loose and discretionary legislation. This increases the mismanagement of public resources.

\section{Empirical Results}

The political business cycle models assume that the incumbents follow expansionary policies just before the elections and reverse the trend after the elections in order to smooth the negative effects of pre-election budget deficits. In such models the elections are assumed to be exogenous and the deficits are endogenous. However, the election time can be endogenous. Incumbents can prefer to hold elections when the social and economic conditions are in their own favor. In order to test whether opportunistic election time hypothesis is valid for Turkey, Tutar and Tansel(2000) performed a Hausman-Wu test, and found that there is no problem of endogeneity of the election time in Turkey ${ }^{6,7}$. In this study, the data set covers the period 1960-2009. In using the 1960-2009 data set, we clearly aim to see the effect of the power dispersion as the fiscal authority was only one (i.e. MOF) before the 1984 and two (MOF and UT) from 1984 onwards $^{8}$. For the whole period after 1983, we use the openness index in order to capture the structural policy switch from import substitution to export promotion policy. The explanatory variables are the lagged values of the dependent variable, inflation rate, the openness index, growth rate of GNP, and some electoral and political dummies. The definition of the variables are given in the next section.

\subsection{Variables}

\subsubsection{The dependent variables}


The dependent variables are Budget Deficit/GNP, Budget Expenditures/GNP and Budget Revenues/GNP. The budget deficit is defined as 'budget revenues minus budget expenditures'.

\subsubsection{Explanatory Variables}

Openness Index: Volume of trade/GNP. The volume of trade is defined as the sum of the export and import values. This variable is assumed to capture the structural policy changes that occurred after 1983.

Military-Backed Governments: Dummy variable for extraordinary (military-backed) governments. Extraordinary governments were in office during three periods: 30 May 1960-28 October 1961; 26 March 1971-16 December 1973; and 12 September 1980-24 November 1983. This variable takes the value of 1 during the extraordinary years, zero otherwise.

Election: Dummy variable for elections. Created by using the Schuknecht (1996)'s definition as follows. We expect economic expansion this year (t) if the election is held within January-April in the next year $(\mathrm{t}+1)$; and the contraction in the same year $(\mathrm{t})$ if the election is held in January or February in that year $(\mathrm{t})$; and contraction in the next year( $(t+1)$ if it is held between March and December of the year $(t)$.

We use the values of 1, -1, 0 for next, previous and current years, respectively, for the election dummy. We took both the nationwide local and the central elections into account. Local elections are held for municipalities. Central elections are held for the parliament.

Number of Authorities: This is the number of fiscal authorities. There was only one organization during the period 1960-1983, which was the Ministry of Finance (MOF). The number of fiscal authorities was two after 1983. The Undersecretariat of the Treasury (UT) was separated from the MOF and began planning and implementing the budget's cash flow and transfer policies including the management of the debt service. This variable takes the value of ' 1 ' before 1984 , and ' 2 ' for 1984 onwards.

Number of Parties: The number of parties (P) in the government. If the number of parties is equal to or greater than two, then it indicates a coalition. In order to find $\mathrm{P}$, we take the number of months into account by multiplying P by the monthly duration of a cabinet in force within a year. Therefore, we use 1 when referring to whole year while we use the number of months over twelve if the governance is less than a year. 
Roubini-Sachs Index (POL) : This index is the political dispersion index constructed in an identical way to that of the Roubini and Sachs (1989a). (See the endnote 4 of this paper).

POL1, POL2 and POL3 are political dummy variables used by Edin and Ohlsson (1991). POL1 assumes a value of 1 for two-party coalitions and zero otherwise. POL2 assumes a value of 1 for three or more party coalitions and zero otherwise. POL3 assumes a value of 1 for minority governments and zero otherwise.

Fractionalization Index (FI): Fractionalization index might be used in order to find the degree of dispersion in a coalition government. It shows the probability that two randomly selected individuals are not from the same group. This index is also used to define that two randomly selected ministers are not from the same party in a coalition government. Fractionalization index (FI) is defined as follows:

$$
F I_{j}=1-\sum_{i=1}^{k} n_{i j}^{2}
$$

Where $\mathrm{i}=1 \ldots . \mathrm{k}$ and $\mathrm{n}_{\mathrm{ij}}=\mathrm{N}_{\mathrm{i}} / \mathrm{M}_{\mathrm{j}}$. Here, $\mathrm{N}_{\mathrm{i}}$ represents party $\mathrm{i}$ 's seats in the government $\mathrm{M}_{\mathrm{j}}$. $\mathrm{FI}_{\mathrm{j}}$ increases as the number of the parties in the coalition increases and reaches a maximum if every seat belongs to a different party. Therefore, if the government consists of one party, FI takes the value of zero, whereas it takes the value of 1 if every seat belongs to a different party in the government. If the seats are equally shared in a two-party coalition, then it will take the value of 0.5 (for more information on the fractionalization index see Annett(2000) and Alesina et al. (2002)). We derived the polarization index for Turkey according to the number of ministers in the coalition governments (for data on coalitions see www.tbmm.gov.tr).

Polarization Index (PI): We will also use the polarization index in order to see the comparative power of coalition members. Polarization index measures how much any two randomly selected coalition members' powers are equal or how far they are from each other. Accordingly, if two parties have equal sizes in a twoparty coalition, then the right-hand side of the formula below will be equal to zero and PI will assume the value of one; if one of them approaches $100 \%$ while the other approaches $0 \%$, then the PI will approach the value of zero. As is the case with the fractionalization index, if the number of the coalition partners are 
increasing in the government, and if their powers in the cabinet are different from each other, then the polarization index will approach 1 . PI is defined as follows:

$$
P I_{j}=1-\sum_{i=1}^{k}\left(\frac{0.5-n_{i j}}{0.5}\right)^{2} n_{i j}
$$

Where $\mathrm{i}=1 \ldots . \mathrm{k}$ and $\mathrm{n}_{\mathrm{ij}}=\mathrm{N}_{\mathrm{i}} / \mathrm{M}_{\mathrm{j}}$ Here, $\mathrm{N}_{\mathrm{i}}$ represents party $\mathrm{i}$ 's seats in the government $\mathrm{M}_{\mathrm{j}}$. (For more information on the polarization index, see Chakravarty, Majumder and Roy (2007) and Araar (2008)). We derived the polarization index for Turkey according to the number of ministers in the coalition governments as we did for the fractionalization index.

Dispersion Index: According to Huber, Kocher and Sutter (2003), dispersion of power within a coalition government can be measured also by the standard deviation of the number of the ministers of the parties in the coalition government. Coalitions with equally strong parties will have lower standard deviation, whereas coalitions with one predominant party will have larger values of standard deviation (i.e. Dispersion). It is expected that higher scores of dispersion demonstrate lower levels of debt and budget deficit, because one strong party in a coalition can put pressure on other coalition members in order to stabilize the budget. For Turkey, we derived the 'Dispersion' index by finding the standard deviations of the coalition governments. Simply, if the number of the ministries of the coalition partners in the government is close to each other, the 'Dispersion' assumed smaller values; but if the coalition members' number of ministries are very much different from each other, the 'Dispersion' assumed higher values. Therefore, it is expected that if the 'Dispersion' increases, then the budget deficit should be affected positively.

Banzhaf Index: Banzhaf index shows bargaining power of a shareholder in a company or that of a coalition member in a government. Sometimes the power of a coalition member cannot be represented by the percentage of seats in the parliament, but its power can also depend on its coalition making or breaking power. Banzhaf Index is usually formulated by the ratio of the probability of swing votes that will be able to determine the failure or success of a coalition to the probability of all set of coalitions (For more information see Banzhaf (1965); Straffin (2002) and Huber, Kocher and Sutter (2003)). For example, if there are four 
parties (A,B,C and D) in a parliament, and if a government needs to have at least $51 \%$ of the seats; and if Party A, B, C, and D have $49 \%, 49 \%, 1 \%$, and $1 \%$ of the seats, respectively, then the voting power of Party $\mathrm{C}$ and D will be zero and that of A and B will be 50-50. The Banzhaf index consists of the sum of such possibilities of voting power of coalition members. The denominator of Banzhaf Index is found by the formula of $2^{\mathrm{n}-1}$ where (n) represents the total number of coalitions. However, voting power of a party just before establishing a government is different (probably less) than after the establishment of the coalition government; because before the establishment, the party, which is endowed with establishing the government, may go to any party to offer partnership. But after the establishment, every member of the coalition government will feel more powerful because the decrees and draft laws require unanimity of the cabinet members; and it is known even by the smaller coalition partners that ending a coalition is not easy, even for the bigger partner. For this reason, we assume that only unanimity of the votes will make sense to pass a decree, which means that the numerator of the Banzhaf Index is just (1). Therefore, a power of a coalition is just equal to the probability of $1 / 2^{\mathrm{n}-1}$. In other words, the bigger the number of coalition members, the less will be the chances of making a decision.

BIXNA and PDI Indices: These are our dispersion indices. BIXNA is a special kind of the Banzhaf Index which accounts also for the number of fiscal authorities. In our model, we propose that if the number of the fiscal authority is more than one, then it means that the fiscal authority that is related to the secondary coalition partner will also behave like another coalition partner; and thus there will be a synchronization problem between these two fiscal authorities. In fact, in the coalition period of 1990's in Turkey, the UT and MOF were shared among the coalition parties. Consequently, usually the UT was related to the coalition party to which the MOF was not related.. Therefore, in contrast to previous studies, we propose that fragmentation of a coalition partner should be measured by $n=$ number of coalition parties + number of additional fiscal authority after 1983 . This variable is almost equal to the inverse of our Power Dispersion Index, which is defined as PDI= Number of Parties * Number of Authorities in Tutar and Tansel (2000). Our index BIXNA, which is roughly PDI, is a special kind of the Banzhaf index with the number of authorities. They both cover the interaction between the power of coalition parties and the fiscal authorities, which was overlooked in the previous studies. In our indices, the interaction means that the probability of making the 
right decision decreases, as two fiscal authorities cannot act together. In this study, we will add the additional fiscal authority as an additional player into $2^{\text {n-1 }}$. The motivation behind this idea is as follows. The annual budget laws are implemented by the bureaucrats of the MOF and the Treasury. Since the budget revenues, expenditures and public debt management need synchronization of the fiscal authorities, cooperative behaviors during the implementation process become as crucial as the projections of the governments. Also, the governments depend on the support of the bureaucrats, especially during the coalitions, in order to play the prisoners' dilemma game against other coalition partners ${ }^{9}$. Therefore, the additional fiscal authority will behave like another coalition partner with respect to the first fiscal authority, which is mostly related to the main coalition partner; and this will make the synchronization more difficult. Consequently, our dispersion indices (BIXNA and PDI) differ from that of previous studies because our indices take fiscal authorities into account as a player.

\subsection{Results of the Analyses (1960-2009)}

The dependent variables are the ratios of budget deficit-to-GNP(BD/GNP), budget expenditures-to-GNP and budget revenues-to-GNP. The dependent variables refer to the consolidated budget which includes the central (ministries) and annexed (universities, state water affairs directorate, state highways directorate, state rural affairs directorate, etc.) budgets; and excludes the budgets of state economic enterprises and the municipalities. Roubini and Sachs(1989a), Edin and Ohlsson (1991), Haan and Sturm(1997), and Huber, Kocher and Sutter(2003) use either debt/GNP or the quantity of money/GNP as the dependent variable. We could not use the debt/GNP because we have problems in unification of external and internal debt as well as their interest rates. In the 1990s, the maturity of the debt was usually more important than the amount of debt itself.. On the other hand, since the financial deepening was not stable during most of the data period, we also do not use quantity of money/GNP as a dependent variable. Thus, we prefer to use the budget variables as the dependent variables, which have quite stable definitions for the whole period.

The OLS estimation results are shown in Tables 3, 4 and 5. In every table there are eight models, each of which explains the same dependent variable. The explanatory variables are lagged dependent variables, growth rate, the dummy for elections, inflation, the dummy for extraordinary governments and openness 
index (volume of trade as a percentage of GNP). The lagged dependent variable allows slow adjustment of budget deficits and also accounts for inertial influences (see Schuknecht, 1996, and Haan and Sturm,1997). One-period-lagged dependent variables are used as explanatory variables in models as suggested by the AIC (Akaike's Information Criterion) test and economic models. In addition to these variables, in the models, there is always one of the eight indices with which we try to explain the power dispersion in Turkish governments between 1960 and 2009. As we explained above, these indices are: the fractionalization index, polarization index, POL, POL1-POL2-POL3, Dispersion, Banzhaf Index, our new index BIXNA (a type of Banzhaf index enlarged with the number of fiscal authorities) and our previous index PDI (number of coalition parties*number of fiscal authorities). We can see the trend of the indices in Figure 3, which clarifies that there is a close relationship among the fractionalization index, polarization index, Banzhaf index, and BIXNA index, while Dispersion and PDI have almost similar trend lines. In order not to crowd Figure 3, we depicted POL, POL1, POL2 and POL3 in Figure 4.

\section{Insert FIGURE 3 and FIGURE 4}

In Table 3, we show the effects of these eight indices on the Budget Deficit/GNP (BD/GNP).

\section{Insert TABLE 3}

According to Table 3, all of the models have high explanatory power because all the coefficients of determination $\left(\mathrm{R}^{2}\right.$ 's) are above $80 \%$ and F-statistics are rather high. The Durbin-Watson (DW) statistic shows that there is no first degree autocorrelation in any of the models. However, since there is a lagged dependent variable in the models, we also checked the LM statistic, which is quite successful in determining the autocorrelation when there is a lagged dependent variable on the right-hand side of the model. As we see in Table 3, Breusch-Godfrey serial correlation LM Test with two lags confirms that there is no autocorrelation in the residuals of the models. We conclude that the models are successful and have high explanatory power. 
In general, the models show that elections and military-backed governments cannot explain the budget deficits significantly, but lagged dependent variable and GDP growth affect the budget deficits statistically significantly and positively. In other words, budget deficits increase as growth rate increases. The ratio of volume of trade to GNP affects budget deficits negatively but its coefficients are significant only in Model 6 and 7. Except the Dispersion Index, POL, POL1 and POL3, all indices explain the budget deficit/GNP ratio statistically significantly. We expect that as fractionalization and polarization of the government increase, the budget deficit also increases. The Banzhaf index and BIXNA explain the budget deficit significantly and positively because as the number of coalition members and fiscal authorities increase, the probability of reaching a consensus in the governments and fiscal authorities decrease; and thus this mechanism increases the prisoner's dilemma cases and hence the deficit. Since PDI is almost the inverse of BIXNA, it affects the budget deficit negatively and significantly, as expected. The index of 'Dispersion' and POL also affect the budget deficits negatively but their coefficients are not statistically significant. Among POL1, POL2 and POL3, only POL2 is statistically significant, and its coefficient is negative, as expected. It means that if the number of the coalition partners is three or more, then the budget performance of the governments decreases significantly.

\section{Insert TABLE 4}

In Table 4, we present the regressions of the budget expenditures/GNP ratio on all the same explanatory variables as in Table 3. Since the $\mathrm{R}^{2}$ 's are $90 \%$ or above and F-statistics are rather high, all models have high explanatory power. The Durbin-Watson(DW) statistic shows that there is no first degree autocorrelation in any of the models. However, since there is a lagged dependent variable in the models, we again checked the LM tests for autocorrelation. In Table 4, the Breusch-Godfrey serial correlation LM statistics with two lags show that there is no-autocorrelation in the models except Model (8). For this model we performed the ARCH LM test and found that there is no ARCH problem in the model. Except Model (8), we can conclude that the models in Table 4 are successful and have high explanatory power. 
As we observe in Table 4, again elections and military-backed governments do not explain budget expenditures significantly. However, in all models the lagged dependent variable, growth rate, inflation and volume of trade-to-GNP ratio explain the budget expenditures statistically significantly. The coefficients of growth rate and inflation are negative and coefficient of volume of trade-to-GNP is positive, as they are projected in the economic theory. For example, since the budget appropriation has a ceiling, sudden increases or decreases in GNP or inflation, by definition, decrease or increase the percentage of budget deficits with respect to GNP.

Except POL1 and POL3, power dispersion indices also show the existence of dispersion in the coalition governments in terms of budget expenditures. Fractionalization and polarization of the government increase the budget expenditures significantly and positively. The Banzhaf index and BIXNA explain the budget expenditures significantly and negatively. For example, as the number of coalition members and fiscal authorities increase, BIXNA and thus the probability of reaching a consensus gets lower, and thus expenditures decrease more slowly. Since 'Dispersion index' and PDI have significantly positive coefficients, we can claim that power dispersion in the government increases the expenditures. POL also affects the budget expenditure positively and significantly. Among POL1, POL2 and POL3, again only POL2 is statistically significant and its coefficient is positive, as expected.

\section{Insert TABLE 5}

Table 5 shows the regression results of budget revenues/GNP ratio on all the explanatory variables as in Tables 3 and 4 and one of the power dispersion indices. The $\mathrm{R}^{2}$ 's and F-statistics show that all models have high explanatory power. The Durbin-Watson (DW) statistic shows that there is no first degree autocorrelation in any of the models. However, since there is a lagged dependent variable in the models, we again checked for this using the LM test for autocorrelation. The LM test statistic confirms that there is noautocorrelation in the models. However, according to the Jarque-Bera test, Model (8) does not have normal distribution of the residuals. Therefore, except Model (8) (PDI), we can conclude that the models in Table 5 are quite successful and have high explanatory power. 
The results in Table 5 show that again, elections and military-backed governments do not explain budget revenues significantly. However, almost in all models the lagged dependent variable, growth rate, inflation and volume of trade-to-GNP ratio explain the budget revenues statistically significantly with the expected signs. The coefficients of growth rate and inflation are negative and coefficient of volume of trade-to-GNP is positive, which is suitable to the economic theory. Inflationary processes usually shrink the tax base. On the other hand, if the tax system is based on the expenditures for goods and services rather than on the income especially in recent decades, as is the case in Turkey, budget revenues-to-GNP ratio does not increase as GNP grows. Moreover, since there is usually a lag in the tax collection of the past incomes, the current growth rate might not be able to show positive effects on the revenues. The negative effect of inflation on revenues/GNP shows the existence of Tanzi effect. The openness index (volume of trade-to-GNP ratio) affects the revenues positively and significantly.

Except 'Dispersion', POL, and PDI, neither of the dispersion indices statistically significantly affect the budget revenues. Quite interestingly, the coefficients of 'Dispersion', POL and PDI are positive which means that power dispersion in the government causes revenues to increase. This might be happening for three reasons. First, because of the power dispersion, coalition members cannot put pressure on the others in order to decrease the tax rates or announce tax amnesties, both of which require unanimity in the cabinet. Second, the revenue side of the budget is controlled only by the Ministry of Finance, so there is no other tax authority that might cause power dispersion. Third, since most of the taxes are indirectly collected, the politicians cannot intervene with the budget revenues. For these reasons, fractionalization, polarization, Banzhaf and BIXNA indices are not significant in explaining the budget revenues.

In sum, election dummy is not statistically significant in any of the models. Therefore, the annual data does not show the existence of political business cycles (PBC's) for gross sum of expenditures and revenues in Turkey between 1960-2009. However, PBC's might be detected by shorter frequency of data (i.e. monthly and/or quarterly data) and for subtotals of the budget expenditures such as subsidies and other transfers or non-budgetary funds. 


\section{Policy Implications}

This study shows that there is a great deal of power dispersion in the coalition governments in Turkey. Since the data covers quite a long period, almost half a century, it means that fragmented governments and fiscal authorities are the main reasons for low budget performance or at least these two indicators go hand-in-hand. The first important implication of the analysis is that the dispersion of the power might be eliminated by the unification or better synchronization of the MOF and the Treasury. This may also allow the existence of a powerful and single fiscal authority that can resist pressures from political constituencies. This unification is also crucial for the coordination of the fiscal authorities. Moreover, the government should eliminate the asymmetry between the rules of revenue accrual and expenditure accrual in order to increase the strictness in favor of rules rather than discretion. For example, in Turkey, according to the Turkish Constitution, taxes can be imposed only by a new act while most of the transfers (such as duty losses ${ }^{10}$ of State Economic Enterprises and all kinds of incentives) can be increased by a cabinet decree or approval of the finance ministry. This fact also allows dispersion of the expenditures to increase.

Turkey's experience might shed light on many developing countries in some respects. First, coalitions and power dispersions in the government are decreasing the fiscal discipline. Second, fragmentation of the fiscal authorities (i.e. administrations) is exacerbating the dispersion problem in the government. Therefore, a strict fiscal coordination should always be a priority for the governments during coalition periods. The first thing that may be recommended for Turkey and other developing countries is to unify all fiscal authorities or provide better coordination of revenues, expenses, cash flow and financial side of a budget. To depict the importance of the subject, we can think of cases in which the MOF tries to increase the tax collection but at the same time the UT tries to sell the state bonds to the same taxpayers. Another example is the case in which the MOF releases a big percentage of appropriation while the UT is unable to provide enough financing resources. Moreover, the MOF cannot know the future burden of the debts and cannot plan a multi-generation model for interest payments and cash flow without the UT. For these reasons, the fragmented fiscal and economic authorities in such developing countries should be unified or at least in the short-run, tied to a single minister or to a secretary. By doing so, cash flow of the budget might be smoothed 
and activities of the UT cannot hinder the MOF's activities or vice versa. The other implication for the developing countries is that spending money from the budget should be as difficult as accruing and collecting taxes. Developing countries that are suffering from severe budget deficits should even think about making an act for better coordination of fiscal authorities and transparent and simple rules of spending in order to curb the prisoner's dilemma cases. The concept of fiscal authorities should not only include the MOF and the UT, but also include the pricing policies of state economic enterprises, extra budgetary and social security funds. Thus, the budget should be strict, plain, transparent and accountable to the public and should be prepared in a multi-generation manner. Moreover, the budget expenses should be very much parallel to the seasonality in the revenues in order to smooth the economic activities in the markets also.

From the viewpoint of future research, this study implies that fragmentation in fiscal authorities, which has been overlooked in previous studies, should be dealt with more often. In fact, the behavior of the budget and treasury bureaucrats might be just as important as coalition members, because they know the technical details of the budget better than the politicians. Especially during the short-tenured coalition governments and the transition periods of government changes, the budget expenditures and debts are governed by the bureaucrats. Therefore, the bureaucrats behave like acting finance ministers or secretaries. Moreover, both policy makers and researchers should treat budget expenditures and revenues separately because they have different procedures of accruals. The political business cycles should be analyzed with quarterly data instead of annual data in order to capture the short run effects of the budget. In addition to this, one can compare the projected appropriation and realized appropriation in order to see the effects of PBC's on the budgets, because salaries and the transfer items usually increase and long term investments usually decrease before the elections. Also, in economies whose state economic enterprises are holding a significant portion of the manufacturing or service sector such as in Turkey, the governments can manipulate the prices of the public goods and services according to the PBC's (For example see Özatay(1999)). Therefore, the analysis on these kinds of off-budget political instruments should be made separately.

Another interesting topic for future research is the causality between economic crises and fragmentation in power. Turkish data shows that there is a definite relationship between economic crises and coalition periods because the 1974, 1977-1980, 1994 and 2001 crises in Turkey occurred during the coalition periods. 
Detecting the direction of the causality or simultaneity between the economic crises and the fragmentation in the government will shed light on important points in developing countries that are newly democratized. Lastly, the effects of the privatization incomes of the state should be analyzed very carefully because their effects might be followed as an off-budget item, as in the case of Turkey. In recent decades, since Turkey's privatization incomes reached a considerable amount, the budget deficit might have been affected by the privatization incomes. These are left for future research.

\section{CONCLUSIONS}

This paper investigates the effect of political and institutional power dispersion such as coalitions, fragmented governments and fiscal authorities on various measures of the state budget-to-GNP ratio in Turkey. Although, this topic is studied extensively in developed countries, it is investigated less often in developing countries. Therefore, the analysis of the experiences of Turkey provides important policy implications for Turkey and other developing countries. The regression analysis for Turkey during the period of 1960-2009 through the Roubini and Sachs model shows that fragmentation in the fiscal authorities, for example, the separate ministry of finance and the treasury exacerbate the negative effects of fragmented (i.e. coalition) governments. Thus a power dispersion index or variable should cover the interaction between the fiscal authorities as well as the coalition parties that are authorized to prepare and implement the budget. Our indices BIXNA and to a certain degree PDI, which are the novelties of this paper, both of which incorporate the interaction between coalition members and the fiscal authorities, have been very successful in explaining the poor budget deficit performances in the models. The analysis indicates that a separate Treasury from the Ministry of Finance under the existence of coalition governments adversely affects the consolidated budget deficits in Turkey. Sound fiscal policies should begin with the unification or better coordination of the Treasury with the Ministry of Finance in order to reduce the negative effects of political power dispersion.

In this article, the existence of political business cycles (PBC's)is also tested. The regression analysis indicates that annual data does not show the existence of PBC's. Future research should address the political 
business cycles by using quarterly or monthly data and the changes in sub-budget items for election and non-election years.

\begin{tabular}{|c|c|}
\hline $\begin{array}{c}\text { Ibrahim Tutar } \\
\text { Penetra Consulting }\end{array}$ & $\begin{array}{c}\text { Aysit Tansel } \\
\text { Sisli 34360 Istanbul }\end{array}$ \\
$\begin{array}{c}\text { Cumhuriyet Caddesi, No.79-6, Suna Apt, Elmadag, } \\
\text { Tel: 0090(212)234 7077, Fax: 0090(212)2347076 } \\
\text { Ibrahim.tutar@penetra.com.tr }\end{array}$ & $\begin{array}{c}\text { University, 06531 Ankara, Turkey } \\
\text { and }\end{array}$ \\
& $\begin{array}{c}\text { Institute for the Study of Labor (IZA) Bonn, Germany } \\
\text { and }\end{array}$ \\
& $\begin{array}{c}\text { Economic Research Forum (ERF) Cairo, Egypt } \\
\text { Tel: 0090(312) 2102057 } \\
\text { atansel@metu.edu.tr }\end{array}$ \\
\hline
\end{tabular}

\section{NOTES}

1 As Schuknecht (1996, p.158) states, in order to analyze the political business cycles in developing countries, fiscal variables are more appropriate than monetary variables because in these countries the economy is not highly monetized. Since we think that this is also the case in Turkey, we will deal only with fiscal variables.

2 The budget deficits are not the only variables that may be affected by the elections. The number of public sector employees and the prices of goods and services produced by the public sector may also exhibit a pattern concurrent with the elections. The effects of these variables on current budget deficits may not be important in the short run but their long-lasting effects may be serious. These issues are important and should be dealt with separately. These are left for future research.

3 The countercyclical variable in the basic model is expressed as 'the change in the growth rate of GNP'. But some researchers prefer to use only 'the growth rate' of the GNP (for example, see Volverink and Haan, 2000). In this study, we also prefer to use the growth rate.

4 Roubini and Sachs test the proposition that multi-party coalition governments have a bias towards larger 
budget deficits by creating an index, POL . This index measures political structure (e.g. degree of cohesion ) of the national government. POL is defined as follows:

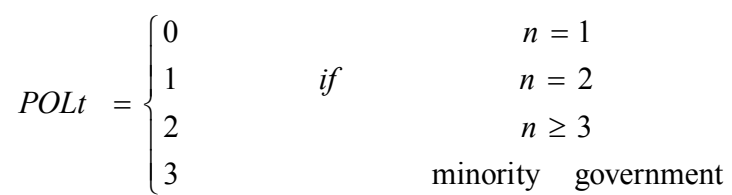

where $\mathrm{n}$ is the number of the parties in the government . Roubini and Sachs also use the variable $\left(\mathrm{POL}_{t} * \mathrm{D}_{\mathrm{t}}\right)$, where $D_{t}$ is a dummy variable which is equal to zero for high growth periods and equal to one for adverse economic circumstances. This variable gives more significant results than $\mathrm{POL}_{\mathrm{t}}$ itself. On the other hand, Roubini (1991) uses frequency of government change- including both regular and irregular changes as a proxy for the degree of political instability. He finds that the greater the frequency of government changes the larger will be the budget deficits. This verifies the proposition of Alesina and Tabellini (1990) who assert that alternative governments after elections strategically influence the choice of their successors. Roubini and Sachs also conclude that military regimes are more successful than democratic ones in stabilization.

5 Gazioglu (1986) found that if the growth rate in Turkey falls, then the size of the sustainable budget deficit is reduced thereby increasing the inflation.

6 Heckelman and Berument(1998) investigated such an issue. By using Hausman procedure with instrumental variable technique, they found some evidence for endogenous elections in Japan but not in England. 7 In order to apply the Hausman-Wu test, Tutar and Tansel have estimated a predicted value of elections with the following equation: Elections $=\mathrm{f}\left(\right.$ Deficit/GNP ${ }_{t}$, Deficit/GNP ${ }_{t-1}$, real budget expenditures, real supplementary budgets). Then they used the predicted values of 'elections' and its original data series in the following equation: Deficit/GNP=f (wars-terrorism, number of parties * number of fiscal authorities, elections, predicted elections) and found residual sum of squares $\left(\mathrm{RSS}_{0}\right)$ and standard error of regression (SER). They also estimated : Deficit/GNP $=\mathrm{f}$ (wars-terrorism, number of parties * number of fiscal authorities, elections) and found $\mathrm{RSS}_{1}$. Finally they computed $\mathrm{X}^{2}(\mathrm{E})=\left(\mathrm{RSS}_{0}-\mathrm{RSS}_{1}\right) / \mathrm{SER}$ where critical value of $\mathrm{X}^{2}(\mathrm{E})$ is approximately $F(1,37)=4.10$. If the $X^{2}(E)$ is less than $F$ value, then it implies that there is no endogeneity problem and OLS gives consistent estimates. Since they found that $\mathrm{X}^{2}(\mathrm{E})=0.0035$, there is no endogeneity problem of elections for the period 1960-1996. See Stewart (1991, p.144-145) and Heckelman and Berument(1998) for more details of the Hausman-Wu test in this context.

8 The Treasury was a general directorate in the Ministry of Finance until December 31, 1983. 
9 Spending items such as transfers to the State Economic Enterprises, incentives from non-budgetary

funds to the agricultural sectors or big infra-structure projects, etc., increase in salaries are good examples for the prisoner's dilemma cases that are subject to the games among coalition partners.

10 If a government assigns a duty to any State Economic Enterprises (SEEs) such as government banks, to intervene with goods and credit markets in order to favor a sector, then losses accrued from this duty is called duty loss.

\section{REFERENCES}

Alesina, Alberto and Roberto Perotti (1995) “'The Political Economy of Budget Deficits," IMF Staff Papers, Vol.42, No.1, March, 1-31.

Alesina, Alberto and Roberto Perotti (1996), 'Fiscal Discipline and the Budget Process,' Proceedings, Vol.86, No.2, May, 401-407.

Alesina, Alberto and Guido Tabellini (1990) 'A Positive Theory of Fiscal Deficits and Government Debt," Review of Economic Studies, Vol.57, 403-414.

Alesina, Alberto, Arnaud Devleeschauwer, William Easterly, Sergio Kurlat, and Romain Wacziarg (2002),

‘'Fractionalization”, National Bureau of Economic Research, Working Paper 9411.

Annett, Anthony (2000), 'Social Fractionalization, Political Instability, and the Size of Governments,'” IMF Working Paper WP/00/82, April.

Araar, Abdelkrim (2008), '’On the Decomposition of Polarization Indices: Illustrations with Chinese and Nigerian Household Surveys,'” Centre Interuniversitaire sur le Risque, les Politiques et l'Emploi (CIRPEE), Working Paper 08-06, May.

Atiyas, Izak (1996) “Uneven Governance and Fiscal Failure: The Adjustment Experience In Turkey,’Pp.285-317, In Governance, Leadership, and Communication ; Building Constituencies for Economic Reforms, (Eds. Leila Frischtak and Izak Atiyas), The World Bank, 1996.

Atiyas, Izak, and Serif Sayin (1997) Political Responsibility, Administrative Responsibility, and Budget System: Towards to Proposition of Restructuring(In Turkish), TESEV Foundation Working Paper (Turkish Foundation of Economic and Social Studies).

Banzhaf, John F. (1965), "Weighted Voting Doesn't Work: A mathematical Analysis", Rutgers Law Review, Vol._19 No.2, 317-343.

Chakravarty, Satya R., Amita Majumder and Sonali Roy (2007), “'A Treatment of Absolute Indices of Polarization,' 
The Japanese Economic Review, Vol.58, No.2. June, pp. 273-293.

Edin, P., and Ohlsson, H. (1991) '’Political Determinants of Budget Deficits: Coalition Effects of Versus Minority Effects,' European Economic Review, Vol.35, 1597-1603.

Engle, R. F. (1982) 'Autoregressive Conditional Heteroscedasticity with Estimates of the Variance of U.K. Inflation," Econometrica, Vol.50, 987-1007.

Ergun, Mine (November-December 2000) ''Electoral Political-Business Cycles in Emerging Markets, Evidence from Turkey," Russian and Eastern European Finance and Trade, Vol.36. No.6, 6-32.

Franzese, Robert J. Jr. (2002) ''Electoral and Partisan Cycles in Economic Policies and Outcomes,' $\underline{\text { Annual Review }}$ of Political Science, 5 .

Gazioglu, Şaziye (1986) " Government Deficits, Consumption and Inflation in Turkey," METU Studies in Development, Vol. 13, No.1-2, 117-134.

Haan, Jakob De And Jan-Egbert Sturm (1994), 'Political and Institutional Determinants of Fiscal Policy in the European Community," Public Choice, Vol.80, 157-172.

Haan, Jakob De And Jan-Egbert Sturm (1997) 'Political and Economic Determinants of OECD Budget Deficits and Government Expenditures: A Reinvestigation,” European Journal Of Political Economy, Vol.13, 739-750.

Haan, Jakob De, Jan-Egbert Sturm And Geert Beekhuis (1999) "The Weak Government Thesis: Some New Evidence,'’ Public Choice, Vol.101, 163-176.

Haan, Jakob De, Jan-Egbert Sturm And Bernd Jan Sikken (1996) 'Government Capital Formation: Explaining the Decline," Weltwirtschafliches Archiv, Vol. 132, No.1, 55-74

Heckelman, Jac C. and Hakan Berument (1998) "Political Business Cycles and Endogenous Elections," $\underline{\text { Southern }}$ Economic Journal, 64(4), 987-1000.

Hibbs, Douglas A. Jr (1977) 'Political Parties and Macroeconomic Policy', The American Political Science Review, Vol.71, 1467-1487.

Huber, Gerald, Martin Kocher and Matthias Sutter (2003), '’ Government Strength, Power Dispersion in Governments and Budget Deficits in OECD-Countries: A Voting Power Approach,” Public Choice, Vol.116, pp.333-350.

Kontopoulos, Y. and R. Perotti (1999) " Government Fragmentation and Fiscal Policy Outcomes: Evidence from OECD Countries," In Poterba, J., And J. Von Hagen (Eds.): Fiscal Institutions And Fiscal Performance. Chicago IL. University Of Chicago Press, 81-102.

Kuştepeli, Yeşim and Gülcan Önel (2005), "'The Effects of Political Fragmentation on Fiscal Deficits in Turkey." Dokuz Eylül University, Faculty of Business, Department of Economics, The Discussion Paper Series, No. 05/2.

Milessi-Ferretti Gian Maria and Enrico Spolaore (1994) 'How Cynical Can an Incumbent Be? Strategic Policy in a Model of Government Spending," Journal Of Public Economics, Vol.55, 121-140.

Nordhaus, William D. (1975) '’The Political Business Cycle,’’ Review of Economic Studies, Vol.42, 169-190. 
Nordhaus, William D. (1989) “'Alternative Models to Political Business Cycles,” Brookings Papers on Economic Activity, Vol.2, 1-50.

Önis, Ziya and James Riedel (1993) The Economic Crisis and Long-Term Growth in Turkey, The World Bank Comparative Macroeconomic Studies.

Özatay, Fatih (1999) "Populist Policies and the Role of Economic Institutions in the Performance of the Turkish Economy," Yapi Kredi Economic Review, Vol.10, No.1, 13-26.

Perotti, Roberto and Yianos Kontopoulos (1998) 'Fragmented Fiscal Policy,', Manuscript, Columbia University.

Phlips, Louis (1988) The Economics of Imperfect Information, Cambridge University Press.

Ricciuti, Roberto (2002) '’Political Fragmentation and Fiscal Outcomes,' Manuscript Presented At 2002 Public Choice Meeting At North Carolina State University.

Roubini, Nouriel (1991) 'Economic and Political Determinants of Budget Deficits in Developing Countries," Journal of International Money and Finance, Vol.10, 49-72.

Roubini, Nouriel and Jeffrey D.Sachs (1989a) 'Political and Economic Determinants of Budget Deficits in the Industrial Democracies," European Economic Review, Vol.33, 903-938.

Roubini, Nouriel and Jeffrey D.Sachs (1989b) ',Government Spending and Budget Deficits in the Industrial Countries," Economic Policy, Vol.8, 99-132.

Sayari, Sabri (1996/97), 'Political Parties, Party Systems, and Economic Reforms: The Turkish Case,' Studies in Comparative International Development, Winter, Vol. 31, No.4, 29-45.

Schuknecht, Ludger (1996) "Political Business Cycles and Fiscal Policies in Developing Countries,” KYKLOS, Vol.49, No.2, 155-170.

Stewart, Jon (1991) Econometrics, Phillip Allan Publishing Company.

Straffin, Philip D. (2002), Game Theory and Strategy, The Mathematical Association of America, No.36, $4^{\text {th }}$ Printing.

Tutar, Ibrahim and Aysit Tansel (2000)_Political Business Cycles, Institutional Structure and Budget Deficits in Turkey, METU, ERC Working Paper, No.00/16.

Varian, Hal R. (1992) Microeconomic Analysis, $3^{\text {rd }}$ Ed., W.W. Norton And Company.

Volkerink, Bjorn And Jakob De Haan (2000) 'Fragmented Government Effects on Fiscal Policy: New Evidence,'” Unpublished Manuscript, University of Groningen. 
TABLES

TABLE-1: Elections and Governments in 1960-2009, Turkey.

\begin{tabular}{|c|c|c|}
\hline Date of the Elections & Duration of the Government & Parties in The Government \\
\hline$\ldots$ & 25.11.1957-27.5.1960 & DP \\
\hline 15.10.1961(CE) & $30.5 .1960-28.10 .1961$ & Extraordinary \\
\hline$\ldots$ & 20.11.1961-1.6.1962 & CHP+AP \\
\hline 17.11.1963(LO) & $25.6 .1962-2.12 .1963$ & $\mathrm{CHP}+\mathrm{YTP}+\mathrm{CKMP}+\mathrm{BG}$ \\
\hline$\ldots$ & $25.12 .1963-13.2 .1965$ & $\mathrm{CHP}+\mathrm{BG}$ \\
\hline $10.10 .1965(\mathrm{CE})$ & $20.2 .1965-22.10 .1965$ & $\mathrm{AP}+\mathrm{CKMP}+\mathrm{MP}+\mathrm{YTP}$ \\
\hline (2.6.1968(LO) & $27.10 .1965-27.10 .1969$ & $\mathrm{AP}+\mathrm{CKMP}+\mathrm{MP}+\mathrm{YTP}$ \\
\hline 12.10.1969(CE) & 3.11.1969-14.2.1970 & AP \\
\hline$\ldots$ & $6.3 .1970-12.3 .1971$ & AP \\
\hline$\ldots$ & 26.3.1971-3.12.1971 & Extraordinary \\
\hline$\ldots$ & 11.12.1971-17.4.1972 & Extraordinary \\
\hline$\ldots$ & $22.5 .1972-10.4 .1973$ & Extraordinary \\
\hline $\begin{array}{ll}14.10 .1973 & (\mathrm{CE}) ; \\
9.12 .1973(\mathrm{LO}) & \end{array}$ & $15.4 .1973-16.12 .1973$ & $\mathrm{AP}+\mathrm{CGP}$ \\
\hline$\ldots$ & 26.1.1974-16.9.1974 & $\mathrm{CHP}+\mathrm{MSP}$ \\
\hline$\ldots$ & $16.11 .1974-31.3 .1975$ & Temporary $(\mathrm{N})$ \\
\hline 5.6.1977(CE) & 31.3.1975-21.6.1977 & $\mathrm{AP}+\mathrm{MSP}+\mathrm{MHP}+\mathrm{CGP}$ \\
\hline$\ldots$ & $21.6 .1977-3.7 .1977$ & CHP(N) \\
\hline 11.12.1977(LO) & 21.7.1977-31.12.1977 & $\mathrm{AP}+\mathrm{MSP}+\mathrm{MHP}$ \\
\hline$\ldots$ & 5.1.1978-17.10.1979 & CHP+BG+CGP+DP \\
\hline$\cdots$ & 12.11.1979-12.9.1980 & $\mathrm{AP}($ minority) \\
\hline$\ldots$ & $22.9 .1980-24.11 .1983$ & Extraordinary \\
\hline $\begin{array}{l}6.11 .1983(\mathrm{CE}) ; \quad 25.3 .1984 \\
(\mathrm{LO})\end{array}$ & 1.3.1983-21.12.1987 & ANAP \\
\hline 29.11.1987 (CE) & $21.12 .1987-09.11 .1989$ & ANAP \\
\hline 26.03 .1989 (LO) & $09.11 .1989-23.06 .1991$ & ANAP \\
\hline 20.10.1991(CE) & $23.06 .1991-20.11 .1991$ & ANAP \\
\hline$\ldots$ & $21.11 .1991-25.06 .1993$ & DYP+SHP \\
\hline $27.03 .1994(\mathrm{LO})$ & $25.06 .1993-05.10 .1995$ & $\mathrm{DYP}+\mathrm{SHP} / \mathrm{CHP}$ \\
\hline $24.12 .1995(\mathrm{CE})$ & $05.10 .1995-30.10 .1995$ & $\mathrm{DYP}+\mathrm{SHP} / \mathrm{CHP}$ \\
\hline .. & $30.10 .1995-06.03 .1996$ & $\mathrm{DYP}+\mathrm{SHP} / \mathrm{CHP}$ \\
\hline$\cdots$ & $06.03 .1996-28.06 .1996$ & ANAP+DYP \\
\hline$\cdots$ & 28.06.1996-30.06.1997 & RP+DYP \\
\hline$\cdots$ & $30.06 .1997-11.01 .1999$ & DSP+ANAP+DTP \\
\hline 18.04.1999(CE and LO) & 11.01.1999-28.05.1999 & DSP(Minority) \\
\hline
\end{tabular}




\begin{tabular}{|c|c|c|}
\hline$\ldots$ & $28.05 .1999-18.11 .2002$ & $\mathrm{DSP}+\mathrm{MHP}+\mathrm{ANAP}$ \\
\hline $3.11 .2002(\mathrm{CE})$ & $(18.11 .2002-14.03 .2003)$ & AKP \\
\hline $\begin{array}{l}\text { 28.3.2004(LO); } \\
\text { 22.7.2007(CE); } \\
\text { 29.3.2009(LO) }\end{array}$ & (14.3.2003-PRESENT) & AKP \\
\hline \multicolumn{3}{|c|}{$\begin{array}{l}\text { Notes: 1)CE shows the central elections; LO, the local ones. 2) Extraordinary governments show the } \\
\text { governments that came to the office after a military intervention. 3) N shows the non-qualified } \\
\text { governments.4) CHP:Republican People's Party, DSP: Democratic Leftist Party; DYP: True Path Party; } \\
\text { RP: Wealth Party; SHP: Social Populist Party; ANAP: Mortherland Party; AP: Justice Party; MHP: } \\
\text { Nationalist Movement Party; MSP: National Salvation Party; DP: Democrat Party; CGP: Republican } \\
\text { Security Party; AKP: Justice and Development Party }\end{array}$} \\
\hline \multicolumn{3}{|c|}{$\begin{array}{l}\text { Source: Sanal, Turker (1995), Turkiye Cumhuriyeti ve } 50 \text { Hukumeti (Turkish Republic and its } 50 \\
\text { Governments), Sim Matbacilı, } 390 \mathrm{p} \text {. and The Website of the Turkish Grand Assembly } \\
\text { (www.tbmm.gov.tr). }\end{array}$} \\
\hline
\end{tabular}

TABLE-2: The Growth, Inflation and Deficit during the period 1960-2009, Turkey

\begin{tabular}{|l|c|c|c|}
\hline & Growth & Inflation & Deficit/GNP \\
\hline $\begin{array}{l}\text { Extraordinary Gov.(1960-61; } \\
\text { 1971-73;1981-83) }\end{array}$ & 0.051 & $18 \%$ & -0.010 \\
\hline Elect Government(1962-1970) & 0.072 & $5 \%$ & -0.009 \\
\hline Elect Government(1974-1980) & 0.028 & $43 \%$ & -0.016 \\
\hline Elect Government(1984-2009) & 0.041 & $48 \%$ & -0.058 \\
\hline Elect Government(1960-2009) & 0.045 & $39 \%$ & -0.038 \\
\hline
\end{tabular}


TABLE-3: OLS ESTIMATION: The Effects of Various Political Factors on Budget Deficit-to-GNP Ratio (BD/GNP), 1960-2009, Turkey

\begin{tabular}{|c|c|c|c|c|c|c|c|c|}
\hline No. of the Model & MODEL 1 & MODEL 2 & MODEL 3 & MODEL 4 & MODEL 5 & MODEL 6 & MODEL 7 & MODEL 8 \\
\hline $\begin{array}{l}\text { Dependent } \\
\text { Variable }\end{array}$ & BD/GNP & BD/GNP & BD/GNP & BD/GNP & BD/GNP & BD/GNP & BD/GNP & BD/GNP \\
\hline Constant & $-0.004(0.54)$ & $-0.006(0.70)$ & $-0.020(1.96)^{* *}$ & $-0.021(2.14)^{*}$ & $-0.008(0.97)$ & $-0.001(0.12)$ & $-0.005(0.53)$ & $0.004(0.39)$ \\
\hline DEPVAR(-1) & $0.646(6.02)^{*}$ & $0.653(6.16)^{*}$ & $0.660(6.09)^{*}$ & $0.651(6.07)^{*}$ & $0.702(6.49)^{*}$ & $0.646(5.64)^{*}$ & $0.494(4.11)^{*}$ & $0.596(5.29)^{*}$ \\
\hline Growth & $0.179(2.87)^{*}$ & $0.184(2.95)^{*}$ & $0.180(2.83)^{*}$ & $0.183(2.92)^{*}$ & $0.189(2.87)^{*}$ & $0.141(2.05)^{*}$ & $0.101(1,53)$ & $0.148(2.34)^{*}$ \\
\hline Election & $-0.001(0.34)$ & $-0.002(0.48)$ & $-0.001(0.30)$ & $-0.001(0.34)$ & $-0.001(0.34)$ & $-0.002(0.48)$ & $-0.003(0.75)$ & $-0.002(0.58)$ \\
\hline Inflation & $-0.003(0.28)$ & $-0.000(0.02)$ & $-0.003(0.32)$ & $-0.001(0.11)$ & $-0.002(0.15)$ & $-0.006(0.60)$ & $-0.012(1,13)$ & $-0.001(0.15)$ \\
\hline $\begin{array}{l}\text { Military Backed } \\
\text { Government }\end{array}$ & $-0.001(0.09)$ & $-0.001(0.09)$ & $-0.000(0.00)$ & $-0.000(0.05)$ & $0.002(0.23)$ & $0.003(0.33)$ & $0.008(0.85)$ & $-0.003(0.32)$ \\
\hline $\begin{array}{ll}\text { Volume } & \text { of } \\
\text { Trade/GNP } & \end{array}$ & $-0.036(1.62)$ & $-0.034(1.54)$ & $-0.035(1.56)$ & $-0.034(1.56)$ & $-0.030(1.32)$ & $-0.041(1.71)^{* *}$ & $-0.03(1.74)^{* *}$ & $-0.030(1,41)$ \\
\hline $\begin{array}{l}\text { Fractionalization } \\
\text { Index }\end{array}$ & $-0.023(2.24)^{*}$ & - & - & - & - & - & - & - \\
\hline $\begin{array}{l}\text { Polarization } \\
\text { Index }\end{array}$ & - & $-0.016(2.30)^{*}$ & - & - & - & - & - & - \\
\hline Banzhaf Index & - & - & $0.015(1.85)^{* *}$ & - & - & - & - & - \\
\hline BIXNA & - & - & - & $0.016(2.14)^{*}$ & - & - & - & - \\
\hline DISPERSION & - & - & - & - & $-0.001(1.13)$ & - & - & - \\
\hline POL & - & - & - & - & - & $-0.005(1.53)$ & - & - \\
\hline POL1 & - & - & - & - & - & - & $0.001(0.19)$ & - \\
\hline POL2 & - & - & - & - & - & - & $-0.044(3.06)^{*}$ & - \\
\hline POL3 & - & - & - & - & - & - & $0.020(1.08)$ & - \\
\hline PDI & - & - & - & - & - & - & - & $-0.006(2.44)^{*}$ \\
\hline $\mathbf{R}^{2}$ & 0.82 & 0.82 & 0.82 & 0.82 & 0.81 & 0.81 & 0.84 & 0.83 \\
\hline Adjusted R ${ }^{2}$ & 0.79 & 0.79 & 0.78 & 0.79 & 0.77 & 0.78 & 0.81 & 0.80 \\
\hline Durbin Watson & 2.04 & 2.01 & 2.01 & 2.03 & 1.96 & 1.95 & 2.09 & 2.10 \\
\hline F-Statistics & 27.04 & 27.22 & 25.90 & 26.73 & 24.35 & 25.11 & 23.39 & 27.70 \\
\hline $\begin{array}{r}\text { Breusch-Godfrey } \\
\text { Serial } \\
\text { Correlation LM } \\
\text { Test(F-Stat) }\end{array}$ & $0.41(0.66)$ & $0.24(0.79)$ & $0.42(0.66)$ & $0.89(0.42)$ & $0.10(0.90)$ & $0.12(0.89)$ & $0.41(0.66)$ & $1.05(0.36)$ \\
\hline $\begin{array}{r}\text { Normality } \\
\text { (Jarque-Bera) }\end{array}$ & $1.85(0.40)$ & $2.76(0.25)$ & $2.54(0.22)$ & $3.39(0.18)$ & $4.25(0.12)$ & $1.09(0.58)$ & $0.66(0.72)$ & $0.70(0.71)$ \\
\hline
\end{tabular}

Notes: 1)The numbers in parentheses are absolute value of $\mathrm{t}$ statistics. $*$ and $* *$ show the significant coefficients at $5 \%$ and $10 \%$ significance level, respectively. The number in parentheses nearby the tests show the probability of not rejecting the null hypotheses of the corresponding tests. 2) Breusch-Godfrey Serial Correlation LM Test(F-Stat) is conducted with two lags. The figures in parenthesis show the probability values. The zero probability value strongly indicates the presence of serial correlation. 3)Under the null hypothesis of a normal distribution, the Jarque-Bera statistic is distributed as $\mathrm{X}^{2}$ with 2 degrees of freedom. The numbers in parenthesis show the probability values. A small probability value leads to the rejection of the null hypothesis of normal distribution. 
TABLE-4: OLS ESTIMATION: The Effects of Various Political Factors on Budget Expenditure-to-GNP

Ratio (BE/GNP), 1960-2009, Turkey

\begin{tabular}{|c|c|c|c|c|c|c|c|c|}
\hline No. of the & MODEL 1 & MODEL 2 & MODEL 3 & MODEL 4 & MODEL 5 & MODEL 6 & MODEL 7 & MODEL 8 \\
\hline $\begin{array}{r}\text { Dependent } \\
\text { Variable }\end{array}$ & BE/GNP & $\mathrm{BE} / \mathrm{GNP}$ & BE/GNP & BE/GNP & BE/GNP & BE/GNP & BE/GNP & BE/GNP \\
\hline Constant & $0.076(4.24)^{*}$ & $0.077(4.21)^{*}$ & $0.102(4.66)^{*}$ & $0.105(4.89)^{*}$ & $0.071(3.90)^{*}$ & $0.078(4.42)^{*}$ & $0.106(5.10)^{*}$ & $0.074(4.39)^{*}$ \\
\hline DEPVAR(-1) & $0.620(6.57)^{*}$ & $0.629(6.60)^{*}$ & $0.626(6.57)^{*}$ & $0.622(6.64)^{*}$ & $0.674(7.13)^{*}$ & $0.528(5.11)^{*}$ & $0.490(4.60)^{*}$ & $0.536(5.69)^{*}$ \\
\hline Growth & $-0.362(3.96)^{*}$ & $-0.366(3.95)^{*}$ & $-0.362(3.91)^{*}$ & $-0.369(4.05)^{*}$ & $-0.380(4.06)^{*}$ & $-0.277(2.97)^{*}$ & $-0.290(3.04)^{*}$ & $-0.318(3.69)^{*}$ \\
\hline Election & $-0.002(0.38)$ & $-0.001(0.23)$ & $-0.002(0.43)$ & $-0.002(0.39)$ & $-0.002(0.43)$ & $0.001(0.21)$ & $-0.000(0.07)$ & $-0.000(0.09)$ \\
\hline $\begin{array}{l}\text { Military } \\
\text { Backed } \\
\text { Government }\end{array}$ & $0.010(0.78)$ & $0.009(0.70)$ & $0.009(0.73)$ & $0.010(0.79)$ & $0.008(0.63)$ & $0.006(0.52)$ & $-0.006(0.48)$ & $0.016(1.32)$ \\
\hline Inflation & $-0.042(2.64)^{*}$ & $-0.043(2.66)^{*}$ & $-0.041(2.55)^{*}$ & $-0.045(2.79)^{*}$ & $-0.045(2.69)^{*}$ & $0.044(2.79)^{*}$ & $-0.036(2.26)^{*}$ & $-0.053(3.39)^{*}$ \\
\hline $\begin{array}{l}\text { Volume } \\
\text { Trade/GNP }\end{array}$ & $0.125(3.28)^{*}$ & $0.121(3.14)^{*}$ & $0.125(3.25)^{*}$ & $0.123(3.25)^{*}$ & $0.113(2.94)^{*}$ & $0.169(4.01)^{*}$ & $0.134(3.49)^{*}$ & $0.127(3.53)^{*}$ \\
\hline $\begin{array}{l}\text { Fractionalizati } \\
\text { on Index }\end{array}$ & $0.037(2.55)^{*}$ & - & - & - & - & - & - & - \\
\hline $\begin{array}{l}\text { Polarization } \\
\text { Index }\end{array}$ & - & $0.024(2.30)^{*}$ & - & - & - & - & - & - \\
\hline Banzhaf Index & - & - & $-0.027(2.32)^{*}$ & - & - & - & - & - \\
\hline BIXNA & - & - & - & $-0.028(2.64)^{*}$ & - & - & - & - \\
\hline DISPERSION & - & - & - & - & $0.003(2.23)^{*}$ & - & - & - \\
\hline POL & - & - & - & - & - & $0.014(2.82)^{*}$ & - & - \\
\hline POL1 & - & - & - & - & - & - & $-0.010(1.06)$ & - \\
\hline POL2 & - & - & - & - & - & - & $0.056(2.82)^{*}$ & - \\
\hline POL3 & - & - & - & - & - & - & $-0.028(1.05)$ & - \\
\hline PDI & - & - & - & - & - & - & - & $0.011(3.56)^{*}$ \\
\hline $\mathbf{R}^{2}$ & 0.90 & 0.90 & 0.90 & 0.90 & 0.90 & 0.90 & 0.91 & 0.91 \\
\hline Adjusted R & 0.88 & 0.88 & 0.88 & 0.88 & 0.88 & 0.89 & 0.89 & 0.90 \\
\hline $\begin{array}{l}\text { Durbin } \\
\text { Watson }\end{array}$ & 2.08 & 2.08 & 2.04 & 2.09 & 1.94 & 2.13 & 1.82 & 2.36 \\
\hline F-Statistics & 52.86 & 51.36 & 51.47 & 53.40 & 50.96 & 54.67 & 42.95 & 60.51 \\
\hline $\begin{array}{r}\text { Breusch- } \\
\text { Godfrey Serial } \\
\text { Correlation } \\
\text { LM Test(F- } \\
\text { Stat) } \\
\end{array}$ & $0.79(0.46)$ & $0.67(0.52)$ & $0.62(0.54)$ & $0.88(0.42)$ & $0.08(0.93)$ & $0.45(0.64)$ & $0.37(0.69)$ & $3.58(0.04)^{*}$ \\
\hline $\begin{array}{r}\text { Normality } \\
\text { (Jarque-Bera) }\end{array}$ & $2.81(0.25)$ & $3.63(0.16)$ & $2.72(0.26)$ & $3.39(0.18)$ & $2.03(0.36)$ & $0.82(0.66)$ & $1.70(0.43)$ & $0.27(0.12)$ \\
\hline
\end{tabular}

Notes: 1)The numbers in parentheses are absolute value of $t$ statistics. ${ }^{*}$ and $* *$ show the significant coefficients at $5 \%$ and $10 \%$ significance level, respectively. The number in parentheses nearby the tests show the probability of not rejecting the null hypotheses of the corresponding tests. 2) Breusch-Godfrey Serial Correlation LM Test(F-Stat) is conducted with two lags. The figures in parenthesis show the probability values. The zero probability value strongly indicates the presence of serial correlation. 3) Under the null hypothesis of a normal distribution, the Jarque-Bera statistic is distributed as $\mathrm{X}^{2}$ with 2 degrees of freedom. The numbers in parenthesis show the probability values. A small probability value leads to the rejection of the null hypothesis of normal distribution. 
TABLE-5: OLS ESTIMATION: The Effects of Various Political Factors on Budget Revenues-to-GNP Ratio (BR/GNP), 1960-2009, Turkey

\begin{tabular}{|c|c|c|c|c|c|c|c|c|}
\hline No. of the & MODEL 1 & MODEL 2 & MODEL 3 & MODEL 4 & MODEL 5 & MODEL 6 & MODEL 7 & MODEL 8 \\
\hline $\begin{array}{c}\text { Dependent } \\
\text { Variable }\end{array}$ & BR/GNP & BR/GNP & BR/GNP & BR/GNP & BR/GNP & BR/GNP & BR/GNP & BR/GNP \\
\hline Constant & $0.084(4.23)^{*}$ & $0.085(4.23)^{*}$ & $0.095(4.47)$ & $0.096(4.53)^{*}$ & $0.081(4.12)^{*}$ & $0.090(4.72)^{*}$ & $0.097(4.46)^{*}$ & $0.083(4.34)^{*}$ \\
\hline DEPVAR(-1) & $0.554(5.44)^{*}$ & $0.555(5.41)^{*}$ & $0.553(5.45)$ & $0.554(5.48)^{*}$ & $0.578(5.75)^{*}$ & $0.475(4.59)^{*}$ & $0.514(4.78)^{*}$ & $0.519(5.22)^{*}$ \\
\hline Growth & $-0.197(2.72)^{*}$ & $-0.198(2.705)^{*}$ & $-0.198(2.73)$ & $-0.200(2.77)^{*}$ & $-0.209(2.92)^{*}$ & $-0.156(2.19)^{*}$ & $-0.187(2.40)^{*}$ & $-0.178(2.54)^{*}$ \\
\hline Election & $-0.003(0.79)$ & $-0.003(0.724)$ & $-0.003(0.83)$ & $-0.003(0.81)$ & $-0.003(0.90)$ & $-0.003(0.681)$ & $-0.003(0.72)$ & $-0.002(0.62)$ \\
\hline $\begin{array}{l}\text { Military } \\
\text { Backed } \\
\text { Government }\end{array}$ & $0.009(0.95)$ & $0.008(0.86)$ & $0.010(0.98)$ & $0.010(0.99)$ & $0.010(1.07)$ & $0.009(0.96)$ & $0.001(0.13)$ & $0.013(1.31)$ \\
\hline Inflation & $-0.050(3.63)^{*}$ & $-0.050(3.54)^{*}$ & $-0.050(3.66)$ & $-0.051(3.72)^{*}$ & $-0.054(3.90)^{*}$ & $-0.056(4.14)^{*}$ & $-0.046(3.23)^{*}$ & $-0.056(4.10)^{*}$ \\
\hline $\begin{array}{l}\text { Volume of } \\
\text { Trade/GNP }\end{array}$ & $0.097(3.93)^{*}$ & $0.097(3.88)^{*}$ & $0.098(3.98)$ & $0.097(3.92)^{*}$ & $0.096(3.94)^{*}$ & $0.118(4.68)^{*}$ & $0.092(3.56)^{*}$ & $0.091(3.79)^{*}$ \\
\hline $\begin{array}{l}\text { Fractionaliza } \\
\text { tion Index }\end{array}$ & $0.014(1.24)$ & - & - & - & - & - & - & - \\
\hline $\begin{array}{l}\text { Polarization } \\
\text { Index }\end{array}$ & - & $0.007(0.91)$ & - & - & - & - & - & - \\
\hline $\begin{array}{l}\text { Banzhaf } \\
\text { Index }\end{array}$ & - & - & $-0.011(1.30)$ & - & - & - & - & - \\
\hline BIXNA & - & - & - & $-0.011(1.41)$ & - & - & - & - \\
\hline $\begin{array}{l}\text { DISPERSIO } \\
\mathbf{N} \\
\end{array}$ & - & - & - & - & $0.002(1.78)^{* *}$ & - & - & - \\
\hline POL & - & - & - & - & - & $0.008(2.32)^{*}$ & - & - \\
\hline POL1 & - & - & - & - & - & - & $-0.008(1.12)$ & - \\
\hline POL2 & - & - & - & - & - & - & $0.012(0.83)$ & - \\
\hline POL3 & - & - & - & - & - & - & $-0.008(0.37)$ & - \\
\hline PDI & - & - & - & - & - & - & - & $0.005(2.18)^{*}$ \\
\hline $\mathbf{R}^{2}$ & 0.85 & 0.85 & 0.85 & 0.85 & 0.86 & 0.86 & 0.86 & 0.86 \\
\hline Adjusted $\mathbf{R}^{2}$ & 0.83 & 0.82 & 0.83 & 0.83 & 0.83 & 0.84 & 0.82 & 0.84 \\
\hline $\begin{array}{l}\text { Durbin } \\
\text { Watson }\end{array}$ & 2.09 & 2.08 & 2.10 & 2.11 & 2.13 & 2.25 & 1.87 & 2.24 \\
\hline F-Statistics & 33.74 & 33.09 & 33.88 & 34.16 & 35.27 & 37.33 & 25,52 & 36.73 \\
\hline $\begin{array}{r}\text { Breusch- } \\
\text { Godfrey } \\
\text { Serial } \\
\text { Correlation } \\
\text { LM Test(F- } \\
\text { Stat) }\end{array}$ & $0.47(0.63)$ & $0.41(0.67)$ & $0.51(0.61)$ & $0.64(0.53)$ & $0.79(0.46)$ & $1.41(0.26)$ & $0.53(0.59)$ & $1.25(0.30)$ \\
\hline $\begin{array}{r}\text { Normality } \\
\text { (Jarque- } \\
\text { Bera) }\end{array}$ & $3.14(0.21)$ & $2.94(0.23)$ & $0.49(0.17)$ & $3.51(0.17)$ & $2.41(0.30)$ & $2.91(0.23)$ & $1.16(0.56)$ & $5.33(0.07)^{*}$ \\
\hline \multicolumn{9}{|c|}{$\begin{array}{l}\text { Notes: 1)The numbers in parentheses are absolute value of t statistics. }{ }^{*} \text { and }{ }^{* *} \text { show the significant coefficients at } 5 \% \text { and } 10 \% \text { significance } \\
\text { level, respectively. The number in parentheses nearby the tests show the probability of not rejecting the null hypotheses of the corresponding } \\
\text { tests. 2) Breusch-Godfrey Serial Correlation LM Test(F-Stat) is conducted with two lags. The figures in parenthesis show the probability } \\
\text { values. The zero probability value strongly indicates the presence of serial correlation. 3)Under the null hypothesis of a normal distribution, } \\
\text { the Jarque-Bera statistic is distributed as } \mathrm{X}^{2} \text { with } 2 \text { degrees of freedom. The numbers in parenthesis show the probability values. A small } \\
\text { probability value leads to the rejection of the null hypothesis of normal distribution. }\end{array}$} \\
\hline
\end{tabular}




\section{FIGURES}

Figure 1. The GNP Growth, and the Ratio of the Budget Deficit to GNP (BD/GNP), 1960-2009, Turkey

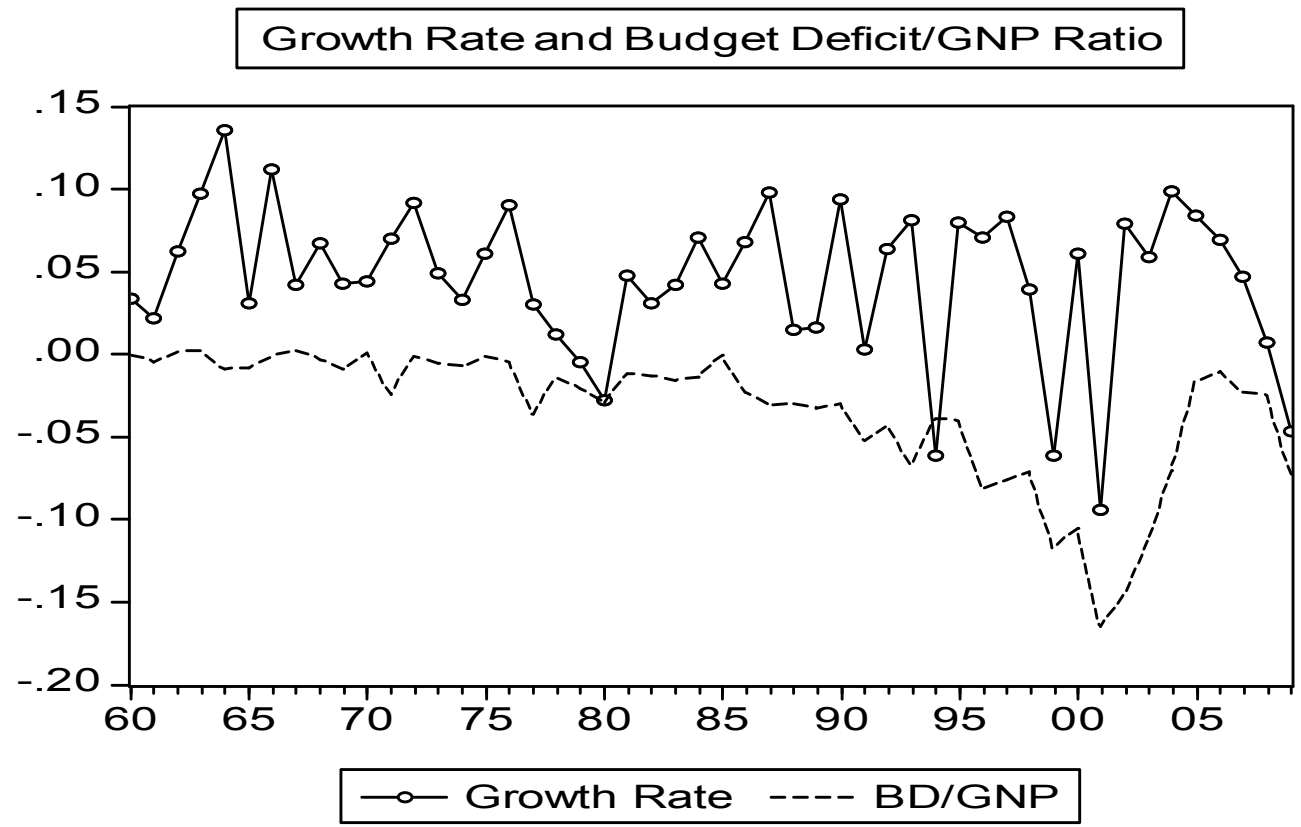

Figure 2. The Rates of Inflation and Number of Parties in the Government, 1960-2009, Turkey

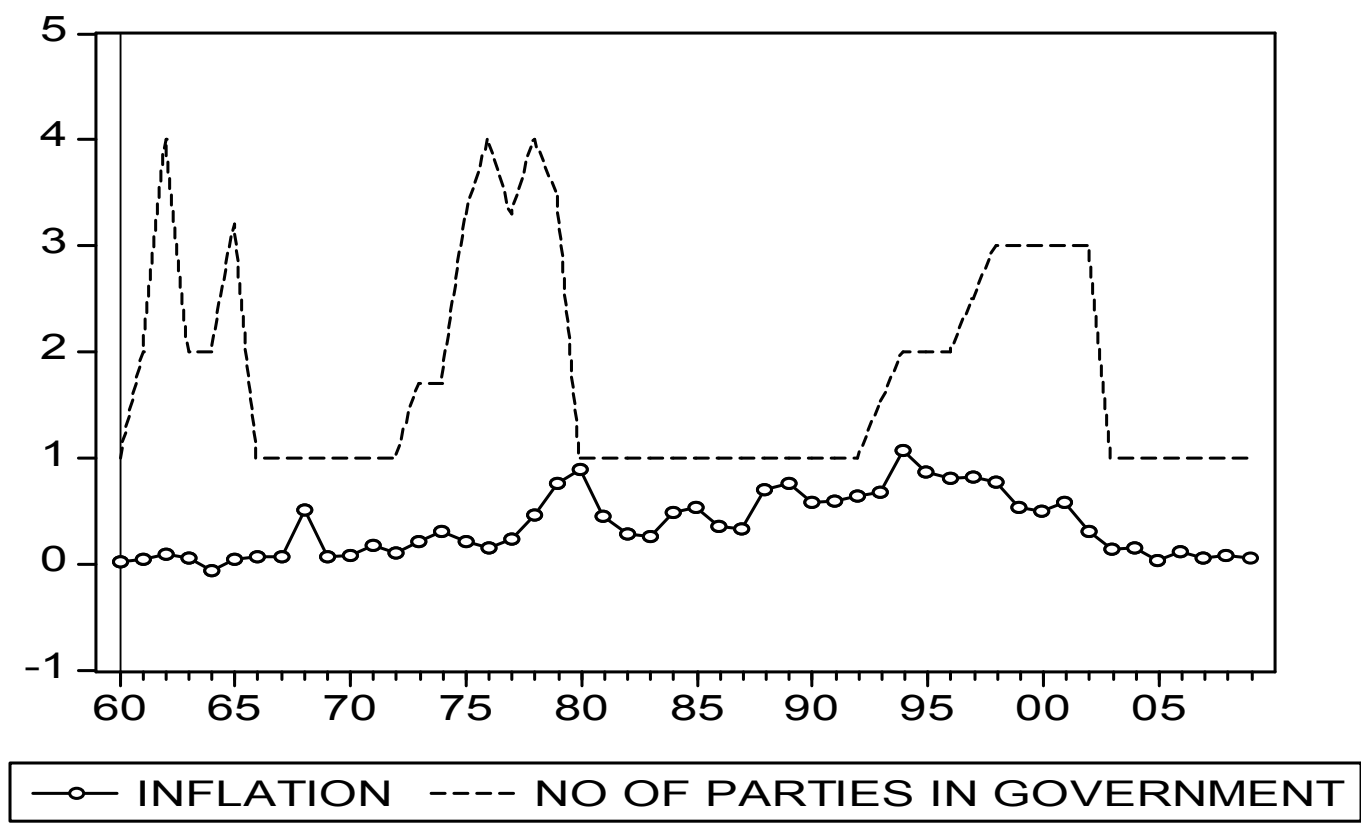


Figure 3. The Trends in Power Dispersion Indices, 1960-2009, Turkey.

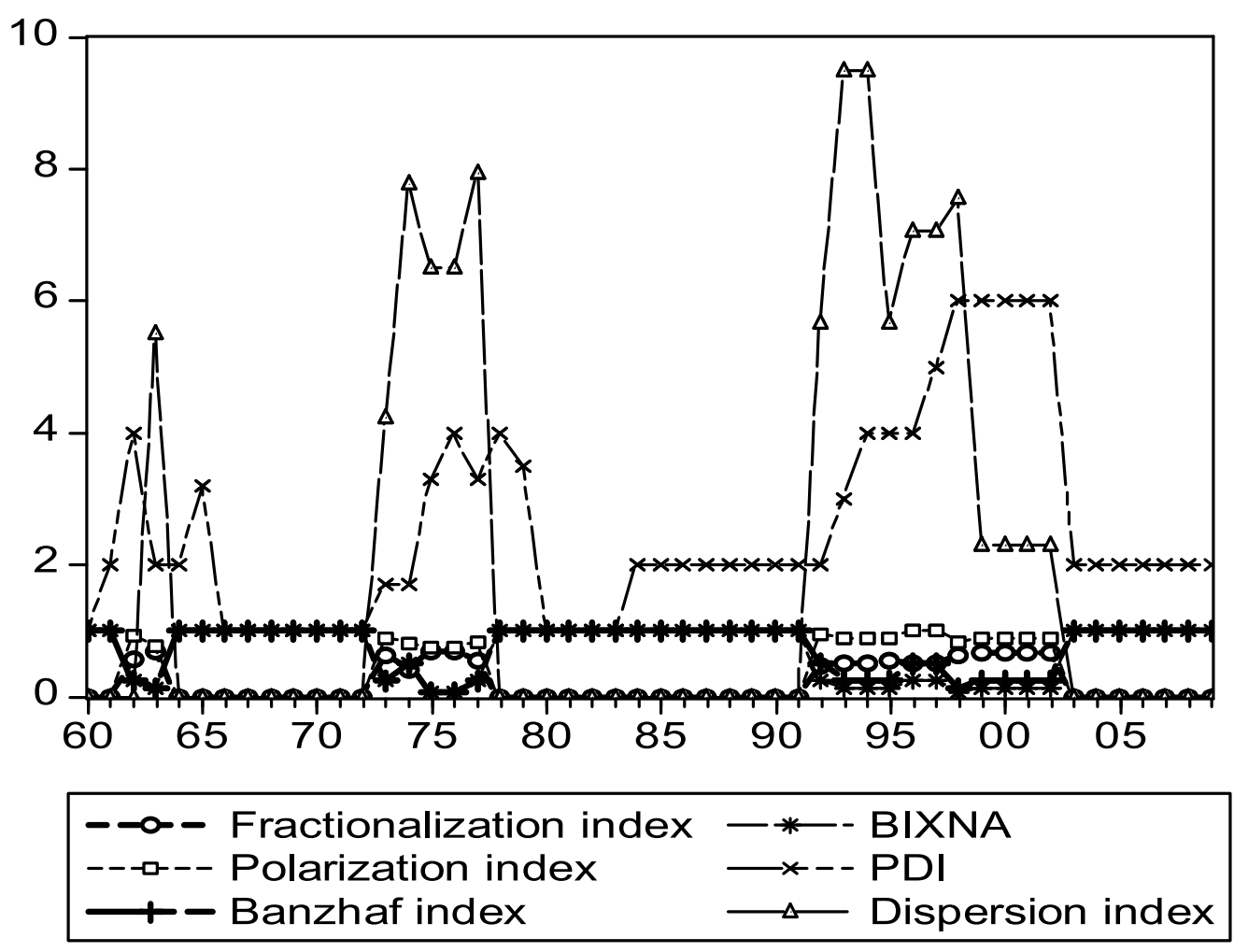

Figure 4. The Trends in POL, POL1, POL2 and POL3, 1960-2009, Turkey.

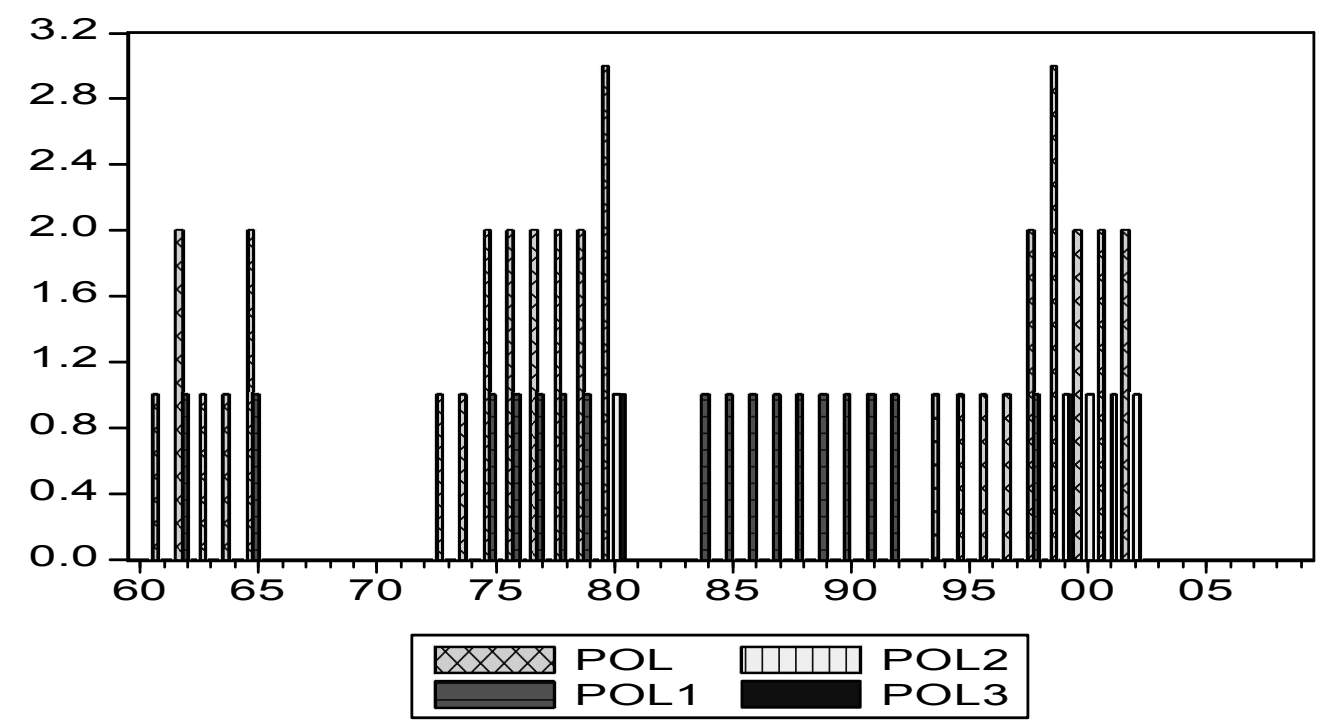

